\title{
Genetic divergence among maize hybrids by morphological descriptors
}

\author{
João Paulo Gonsiorkiewicz Rigon ( ${ }^{1 *}$ ); Silvia Capuani (2); Carlos Alberto Gonsiorkiewicz Rigon ( ${ }^{3}$ ) \\ (1) Universidade Estadual Paulista (UNESP), Faculdade de Ciências Agronômicas (FCA), Departamento de Fitotecnia, \\ Rua José Barbosa de Barros, 1780, 18610-307 Botucatu (SP), Brasil. \\ (2) UNESP, FCA, Departamento de Ciência do Solo, 18610-307 Botucatu (SP), Brasil. \\ (3) Universidade Federal de Santa Maria (UFSM/CESNORS), Linha 7 de Setembro, s/n, BR 386, km 40, 98400-000 \\ Frederico Westphalen (RS), Brasil. \\ (*) Corresponding author: jprigon@fca.unesp.br
}

Received: Aug. 1, 2014; Accepted: Jan. 16, 2015

\begin{abstract}
Two experiments with 25 maize commercial hybrids were carried out in a direct sowing system in Southern Brazil in the harvests of 2009/2010 and 2010/2011. Quantitative descriptors were used with the objective of determining the genetic divergence and the relative contributions of traits among hybrids for extraction of inbred lines. This study was carried out in Oxisol soil using a randomized block design with four replicates. Data were subjected to combined analysis of variance, and based on the multivariate analyses, Tocher and average linkage (UPGMA) cluster analyses, based on generalized distance of Mahalanobis, to quantify divergence in addition to Singh criterion to validate trait with the most contribution. The multivariate methods were consistent with each other, and the weight of 100 grains was the trait that contributed most to the divergence and had similar behavior in grain yield between hybrids in both years. Furthermore, this descriptor representing significant genetic variability for crossings and lines extraction to hybridization between BM 3061, ATL 200 and P 30B39 Y.
\end{abstract}

Key words: divergence quantitative descriptors, multivariate analyses, Zea mays.

\section{INTRODUCTION}

The domestication process and the successive events after selection in the maize crop resulted in reduced diversity of the crop, when compared to the parent population (Tenaillon et al., 2004). Information about agronomic superiority or genetic divergence make it possible the combination of parents, identifying the wider gene set and viability of crossings. Therefore, improved maize populations allow the development of new lines with a good capacity of recombining amongst each other. In addition, there is the possibility of boasting more and more compensatory increments according to the breeding among divergent lines (Carena, 2005).

The analysis of genetic diversity aims at predicting combinations with higher heterozygosity so that there will be more possibilities of recovering higher genotypes in the segregant generations (Troyer, 2006). Distribution among groups allows the early determination of the best combinations, and, therefore, reduces the number of unneeded crosses, priorizing more constrastant groups for obtantion of combination with higher heterosis (Moro et al., 2007). Morphological, physiological and productive differences are regarded in quantification of dissimilarity. Those genetic variations among maize cultivars are essential for predicting heredity and level of heterosis, which are essential for crop production (Duan et al., 2006). Association degree among traits allows the use of indirect selection over another variable, especially when heritability of the principal trait is low, as is the case for yield, for example (Iqbal et al., 2003).

Advances in plant breeding have come from studies on quantitative genetics, which have contributed in the selection of higher cultivars (Hallauer, 2007). Beyene et al. (2005), in a study comparing phenotypic and molecular methods to estimate genetic divergence, concluded that both methods are equally suited to study genetic diversity in the maize crop.

Studies on maize crop showed combinations of crossings and parent extraction to estimate genetic gain, as reported by Dotto et al. (2010) in low altitudes, in Coimbra et al. (2010) in maize landraces, and Paixão et al. (2008). Determination of heterotic groups and heterotic patterns is of fundamental importance in the improvement of maize hybrids. However, there is a need for studies on diversity among current maize hybrids with results for 
more than one harvest. Thus, the objectives of this study were to evaluate the genetic diversity of 25 mayze hybrids based on quantitative traits using multivariate techniques and obtain the relative contribuitions according to extraction lines to be used in breeding programs.

\section{MATERIALS AND METHODS}

Two experiments were carried out in Rio Grande do

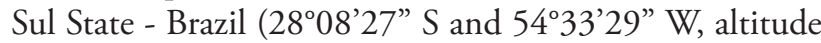
of $270 \mathrm{~m}$ ) for the harvests of 2009/2010 and 2010/2011. The climate in the region is humid mesothermal Cfa, and the soil used in the experiment was dystrophic Red Latosol (EMBRAPA, 2006). The experiment was conducted on direct sowing of forage turnip straw (4.9 and $6.3 \mathrm{Mg} \mathrm{ha}^{-1}$, respectively).

Twenty-five maize hybrids were evaluated in a random block design with four replicates. Plots were $5.6 \mathrm{~m} \mathrm{x} 5 \mathrm{~m}$, and so they were fitted with 8 cultivation rows, spaced $0.7 \mathrm{~m}$ apart.

Sowing was done in the first 10-day period in August 2009 and 2010, aiming at a population of 60,000 plants $\mathrm{ha}^{-1}$. Foundation fertilization was perfomed according to the chemical characteristics of the soils: clay $=58$ and $65 \% ; \mathrm{pH}=5.7$ and 5.8; SMP index $=6.3$ and 5.9; phosphorus $=4.2$ and $4.8 \mathrm{mg} \mathrm{L}^{-1}$; potassium $=95$ and $82 \mathrm{mg} \mathrm{L}^{-1}$; O.M. $=2.8$ and $2.9 \%$; cation exchange capacity $=19.43$ and $24.05 \mathrm{cmolc} \mathrm{L}^{-1}$; base saturation $=83.4$ and $86 \%$ and according to the recommendation of Comissão de Química e Fertilidade do Solo (CQFS, 2004) as well; therefore, $250 \mathrm{~kg} \mathrm{ha}^{-1}$ of the NPK mineral formulation 5-20-20 was used. Two side-dressed $\mathrm{N}$ applications of $60 \mathrm{~kg} \mathrm{ha}^{-1}$ were carried out, using urea as source at the stages V4 and V6. Atrazine and Nicosulfuron-based herbicides were used to control weeds, and chlorpyriphos and cipermetrine-based insecticides were used to control pests.

Based on the useful area of the plot, the following morphological descriptors were assessed: height of the plants (HP); height of ear insertion (HEI); size of the ear (SIE); grain weight per ear (MGE); number of grains per ear (NGE) - mean between weight 100 grain and grain weight per ear; 100-grain weight (M100); and grain yield (GY), corrected for $13 \%$ of moisture.

Data were subjected to analysis of variance, and for determining genetic diversity, a dispersion matrix was obtained by using multivariate methods based on average linkage grouping among sets (UPGMA) for generating a dendrogram, by using generalized distance of Mahalanobis as a dissimilarity measure. Cluster methods of Tocher, and Singh criterion were used to state the relative significance of the traits studied and variables which most favored genetic dissimilarity were compared by the Scott-Knott test, at $5 \%$ probability. Validation of matrix to dendrogram was determined by cophenetic correlation coefficient. Analyses were done using the software Genes, version 2006 (Cruz, 2006).

\section{RESULTS AND DISCUSSION}

Variability amongst hybrids is found by the remarkable coefficient of genetic variation $(\mathrm{CVg})$, which expresses the magnitude relative to the average of the traits. By means of the present estimates, it was found that grain yield was the most distinct variable among genotypes (10.97\%), followed by grain weight per ear, height of ear insertion, number of grains per ear and plant height (Table 1). Moreover, the measured traits had significant heritability coefficient, as well as the relationship between coefficients of genetic and enviromental variation $(\mathrm{CVg} / \mathrm{CVe})$, these parameters of confidence in the success of selection for fitter genotypes. Thus, selection is very promising mainly by means of height of the plant, height of ear insertion, size of the ear and number of grains per ear, as a function of the highest assessed herdabilities, as well as high $\mathrm{CVg} / \mathrm{CVe}$. Although influence on genetic gains by these characters, are also relevant relations with grain yield. Therefore, the first two criteria are discarded because they do not are related to the yield of maize grain, unlike with the other variables mostly the weight of 100 grains (Rigon et al., 2014). The value of the predicted gain for these characteristics all together were positive in all the selected criteria, surpassing the estimates with combined gains.

The relative contribution of Singh criterion traits, which are used for expression of genetic divergence among hybrids, showed that AP and M100 were the variables which most favored genetic dissimilarity in the maize, with a contribution of 38 and $18 \%$, respectively. Others studies (Ahmad et al., 2011; Alom et al., 2003) also found in an analysis with maize hybrids that the 100 weight of grains

Table 1. Values by heritability coefficient $\left(\mathrm{H}^{2}\right)$, coefficient of genetic variation $(\mathrm{CVg})$ and ratio coefficient of genetic variation and environmental variation $(\mathrm{CVg} / \mathrm{CVe})$, and the contribution of traits to divergence*

\begin{tabular}{|c|c|c|c|c|c|c|}
\hline Variables & CVg (\%) & CVg/Cve & $\mathrm{H}^{2}$ & S.j. ${ }^{* *}$ & S.j.\% & S.j.ac\% \\
\hline Plant height & 8.01 & 2.41 & 0.83 & 4197.37 & 38.39 & 38.39 \\
\hline $\begin{array}{l}\text { Height of ear } \\
\text { insertion }\end{array}$ & 8.52 & 1.44 & 0.76 & 1660.66 & 15.19 & 53.59 \\
\hline Ear size & 7.56 & 1.26 & 0.85 & 527.34 & 4.82 & 58.41 \\
\hline $\begin{array}{l}\text { Grain weight } \\
\text { per ear }\end{array}$ & 8.71 & 0.82 & 0.58 & 707.22 & 6.46 & 64.88 \\
\hline $\begin{array}{l}\text { Number of } \\
\text { grains per ear }\end{array}$ & 8.22 & 1.07 & 0.71 & 1126.23 & 10.30 & 75.18 \\
\hline $\begin{array}{l}\text { Weight of } \\
100 \text { grains }\end{array}$ & 3.36 & 1.14 & 0.42 & 2115.98 & 19.35 & 94.54 \\
\hline Grain Yield & 10.97 & 0.86 & 0.64 & 596.30 & 5.45 & 100 \\
\hline
\end{tabular}

each variable $\mathrm{j}$ for the study of genetic diversity. 
and height of the plants were the traits with the greatest variability and contribution to genetic divergence, although the variable height of plant has no significant effect on grain yield in maize as previously commented.

The behavior of the parameter with higher contribution in the divergence between hybrids and better genetic gains is important in grain yield. By analyzing the weight of 100 grains as like as the yield in both years (Figure 1), it can be said that hibrids behavior was similar among treatments ranging from the years. However, overall maize grain yield (Figure 2) was higher in the 2010/2011 harvest, while the weight of 100 grains was higher in the previous harvest. This can be observed through the same yield among the crops of hybrid DW2A120h, SHS7090, P30F53 and P1630 while the agglomeration for each genotype was distinct through the Scott Knot test, as well as hybrid SHS5050 of weight of 100 grains.

Independent of the harvest the highest yield can be observed in hybrids mainly on the 4th and 3rd quarters in figure 2, which is repeated the weight of 100 grains in figure 1 . This similar behavior of hybrid shows that the weight of 100 grains besides the factors of variation and heritability previously mentioned, influences the yield independent of the type of hybrid.

The Tocher cluster method, obtained from the matrix of generalized distance of Mahalanobis, classified maize hybrids into five groups (Table 2). Alom et al. (2003), also in an analysis with 25 maize hybrids, found the formation of seven clusters. Although the distances had high representativeness, formation of clusters is very important in choosing parents because the new material to be set has to be based on the observed dissimilarities.

Fifteen hybrids were ordered in the group I, representing more than half of the analyzed cultivars, followed by group II and group III, with six and two hybrids, respectively, whereas groups IV and $\mathrm{V}$ were formed by only one genotype. It can be seen that the other hybrids were responsible for the smaller yields, except for group I. In addition, only hybrids P 30B39 Y and SHS 7090 are the simple-type hybrids, whereas group I is formed mostly by this type, together with the triple hybrids.

Formation of clusters shows good representativeness of divergence, as was also found by Dotto et al. (2010) in an analysis with commercial maize cultivars. This divergence

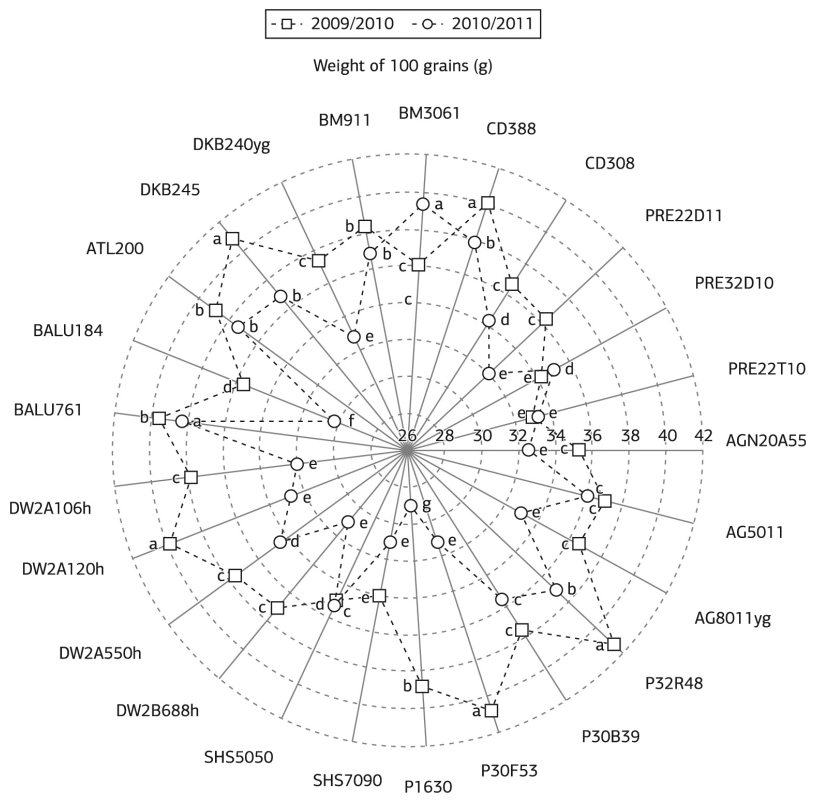

Figure 1. Average of weight of 100 grains of maize hybrids in crops. Averages followed by the same letter in each year are not statistically different among themselves, by Scott-Knott test, at $<0.05$ probability.

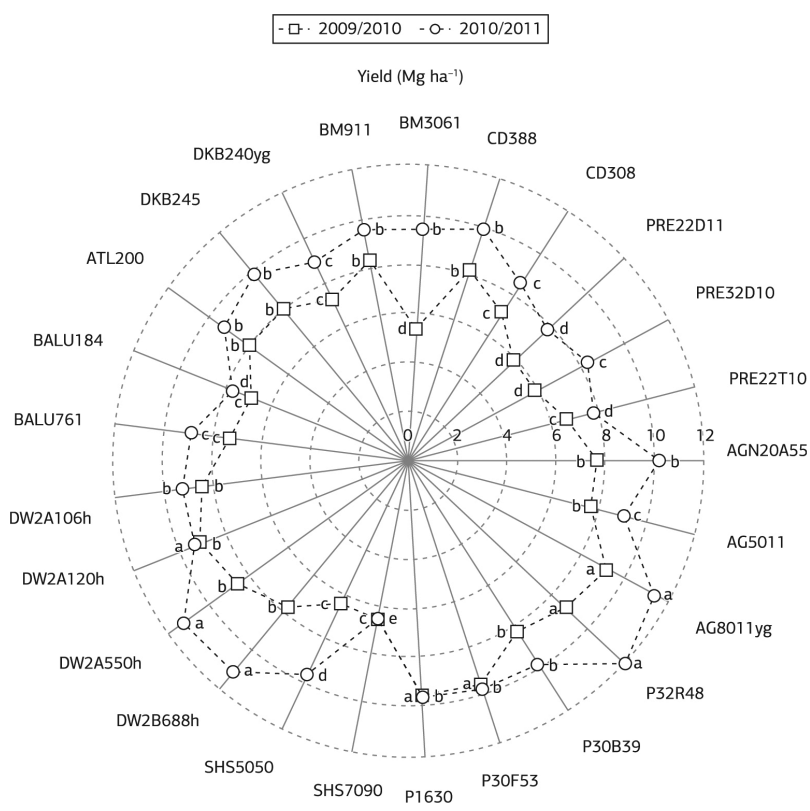

Figure 2. Average of yield of maize hybrids in crops. Averages followed by the same letter in each year are not statistically different among themselves, by ScottKnott test, at $<0.05$ probability.

Table 2. Tocher cluster method obtained from the matrix of generalized distance of Mahalanobis

\begin{tabular}{|c|ccccccc}
\hline Group & \multicolumn{5}{c}{ Hybrids } \\
\hline I & 20A55 & AG 5011 & AG 8011 YG & P 32R48 Y & P 30F53 Y & SHS 5050 \\
& 2B688 & 2A550 Hx & 2A120 Hx & 2A106 Hx & P 1630 & DKB 245 \\
\hline II & DKB 240 YG & BM 911 & CD 388 & & SHS 7090 & BALU 184 \\
\hline III & CD 308 & PRE 22D11 & PRE 32D10 & PRE 22T10 & & \\
\hline IV & P 30B39 Y & ATL 200 & & & \\
\hline V & BALU 761 & & & & \\
\hline
\end{tabular}


in maize may be used in the potential selection of parents for allowing specific combinations amongst hybrids (Barata \& Carena, 2006).

Regarding the matrix of Mahalanobis, maximum and minimum distances of each hybrid are described (Table 3). We found that P $30 \mathrm{~B} 39 \mathrm{Y}$ was more divergent than the other 20 hybrids, whereas the highest similarity was found in $20 \mathrm{~A} 55$ with $2 \mathrm{~B} 688$ and $2 \mathrm{~A} 106 \mathrm{Hx}$, with $\mathrm{D}^{2}=0.6733$ and 0.7508 , respectively.

The dendrogram using the hierarchical method for allocation of hybrids by average linkage among groups

Table 3. Maximum (DMA) and minimum (DMI) distances between the hybrids in the matrix of Mahalanobis

\begin{tabular}{|lrlrl|}
\multicolumn{1}{|c}{ Hybrid } & DMA & \multicolumn{1}{c}{ Hybrid } & DMI & \multicolumn{1}{c}{ Hybrid } \\
\hline 20A55 & 93.28 & P30B39 & 0.67 & 2B688 Hx \\
\hline AG 5011 & 155.61 & P30B39 & 3.05 & BM 911 \\
\hline AG 8011 YG & 111.25 & P30B39 & 4.83 & 2A550 Hx \\
\hline P 32R48 Y & 106.07 & BALU184 & 8.39 & CD 388 \\
\hline P 30B39 Y & 248.09 & BALU184 & 18.89 & ATL 200 \\
\hline P 30F53 Y & 71.47 & P30B39 & 2.88 & 2A106 Hx \\
\hline P 1630 & 97.38 & P30B39 & 4.83 & 2B688 \\
\hline SHS 7090 & 191.76 & P30B39 & 8.04 & BALU 184 \\
\hline SHS 5050 & 112.44 & P30B39 & 3.85 & CD 308 \\
\hline 2B688 & 90.44 & P30B39 & 0.67 & 20A55 \\
\hline 2A550 Hx & 99.68 & P30B39 & 4.79 & 20A55 \\
\hline 2A120 Hx & 72.42 & P30B39 & 3.39 & 2A106 Hx \\
\hline 2A106 Hx & 81.55 & P30B39 & 0.75 & 20A55 \\
\hline BALU 761 & 90.84 & P30B39 & 5.00 & CD 388 \\
\hline BALU 184 & 248.09 & P30B39 & 8.04 & SHS 7090 \\
\hline ATL 200 & 172.87 & BALU184 & 18.89 & P 30B39 Y \\
\hline DKB 245 & 90.72 & P30B39 & 7.52 & CD 388 \\
\hline DKB 240 YG & 104.85 & P30B39 & 4.41 & 2A106 Hx \\
\hline BM 911 & 140.04 & P30B39 & 3.05 & AG 5011 \\
\hline BM 3061 & 125.22 & BALU184 & 23.29 & BALU 761 \\
\hline CD 388 & 91.01 & P30B39 & 5.00 & BALU 761 \\
\hline CD 308 & 149.62 & P30B39 & 3.85 & SHS 5050 \\
\hline PRE 22D11 & 101.40 & P30B39 & 1.77 & PRE 22T10 \\
\hline PRE 32D10 & 131.00 & P30B39 & 5.02 & PRE 22T10 \\
\hline PRE 22T10 & 107.03 & P30B39 & 1.77 & PRE 22D11 \\
\hline & & & & \\
\hline
\end{tabular}

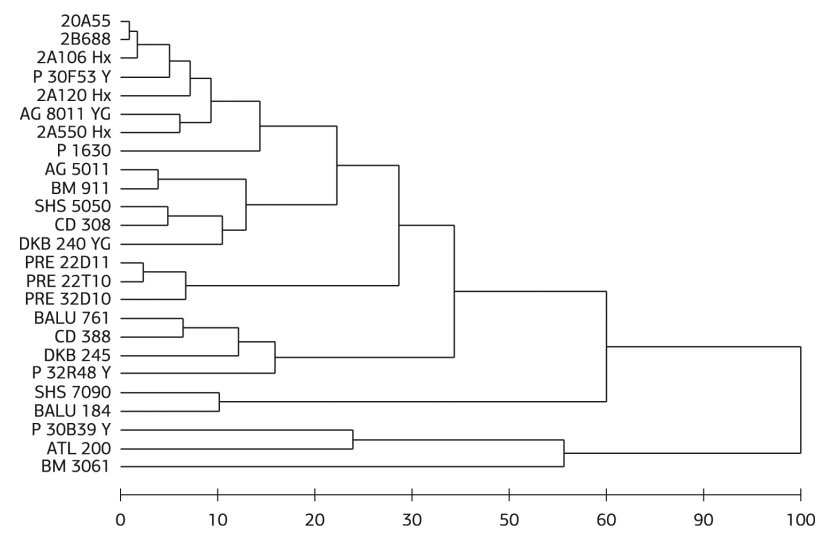

Figure 3. Dendrogram resulting from grouping analysis by the UPGMA method of 25 maize hybrids, using Mahalanobis distance, obtained from quantitative traits analyses.
(UPGMA) was the most precise for genotype clustering, elapsing the cut at the proportion of $40 \%$ of the total genetic distinction by sets agglomeration, as was found by Osorno \& Carena (2008) in a similar study of divergence amongst maize genotypes Rotili et al. (2012), Rigon et al. (2012), with sunflower. Equivalence of the methods was found by the similarity between constitution of Tocher grouping to and the dendrogram (Figure 3). Analyses of clusters points to the genotypes with the highest probability of parents, reducing the number of the combinations needed in a breeding program and increase of heterosis (Mohammadi \& Prasanna, 2003).

The conformation of isolated hybrids in the dendrogram reflects the detachment expressed in the Tocher grouping, being considered as dissimilar to the others, and therefore appropriate for synthesis in hybrid combinations. Therefore, the most similar materials were: 20A55, 2A106 Hx, 2B688, P 30F53 Y, 2A120 Hx, 2A550 Hx and AG 8011, with the recommendation of extraction lines for hybridization with the most divergent: BM 3061, ATL 200 and P 30B39 Y, with a good agreement among the different estimates.

Establishment of heterogeneity among clusters is crucial for estimating genetic divergence amongst hybrids. Moreover, extraction of lines from those improved hybrids is very important because they count upon a great portion of fixed favorable loci, in addition to being tested in different environments (Amorim \& Souza, 2005).

\section{CONCLUSION}

The multivariate methods were consistent with each other, and the weight of 100 grains was the trait that contributed most to the divergence and had similar behavior in grain yield between hybrids in both years. Furthermore, this descriptor representing significant genetic variability for crossings and lines extraction to hybridization between BM 3061, ATL 200 and P 30B39 Y.

\section{REFERENCES}

Ahmad, S. Q., Khan, S., \& Ahmad, G. (2011). Genetic diversity analysis for yield and other parameters in maize (Zea mays L.) genotypes. Asian Journal of Agricultural Sciences, 3, 385-388. Retrieved from http://maxwellsci.com/print/ajas/v3-385-388.pdf

Alom, A. K. M. M., Masum, A. S. M. H., Nahar, N., Matin, M. A., \& Pasha, A. K. M. J. (2003). Genetic divergence in maize (Zea mays L.). Pakistan Journal of Biological Sciences, 622, 1910-1911. http:// dx.doi.org/10.3923/pjbs.2003.1910.1911.

Amorim, E. P. \& Souza, J. C. (2005). Híbridos de milho inter e intrapopulacionais obtidos a partir de populaçóes S0 de híbridos simples comerciais. Bragantia, 64, 561-567. http://dx.doi.org/10.1590/ S0006-87052005000400005. 
Barata, C., \& Carena, M. J. (2006). Classification of North Dakota maize inbred lines into heterotic groups based on molecular and testcross data. Euphytica, 151, 339-349. http://dx.doi.org/10.1007/ s10681-006-9155.

Beyene, Y., Botha, A. M., \& Myburg, A. A. (2005). A comparative study of molecular and morphological methods of describing genetic relationships in traditional Ethiopian highland maize. African Journal of Biotechnology, 4, 586-595. Retrieved from http://www. academicjournals.org/AJb/PDF/Pdf2005/Jul/Beyene\%20et\%20al.pdf

Carena, M. J. (2005). Maize commercial hybrids compared to improved population hybrids for grain yield and agronomic performance. Euphytica, 141, 201-208. http://dx.doi.org/10.1007/s10681-0057072-0.

Coimbra, R. R., Miranda, G., Cruz, C. D., Melo, A. V., \& Eckert, F. R. (2010). Caracterização e divergência genética de populaçóes de milho resgatadas do Sudeste de Minas Gerais. Revista Ciência Agronômica, 41, 159-166. http://dx.doi.org/10.1590/S1806-66902012000300014.

Comissão de Química e Fertilidade do Solo - CQFS (2004). Manual de adubação e calagem para os Estados do Rio Grande do Sul e de Santa Catarina (10th ed.). Porto Alegre: SBCS - Núcleo Regional Sul/UFRGS.

Cruz, C. D. (2006). Programa genes - diversidade genética. Viçosa: UFV.

Dotto, M. A., Afférri, F. S., Peluzio, J. M., Melo, A. V., \& Carvalho, E. V. (2010). Divergência genética entre cultivares comerciais de milho em baixas altitudes no Tocantins, safra 2007/2008. Revista Ciência Agronômica, 41, 630-637. http://dx.doi.org/10.1590/ S1806-66902010000400017.

Duan, Y. P., Chen, W. G., Li, M. S., Li, X. H., Liu, X., Tian, Q. Z., Bai, L., \& Zhang, S. H. (2006). The genetic diversity among 27 maize populations based on SSR data. Science Agronomica Sinica, 39, 1102-1113. Retrieved from http://en.cnki.com.cn/Article_en/ CJFDTOTAL-ZNYK200606002.htm

Empresa Brasileira de Pesquisa Agropecuária - EMBRAPA (2006). Sistema Brasileiro de Classificação de Solos. Rio de Janeiro: Embrapa Solos.

Hallauer, A. R. (2007). History, contribution, and future of quantitative genetics in plant breeding: lessons from maize. Crop Science, 47, 1123-1128. http://dx.doi.org/10.2135/cropsci2007.04.0002IPBS.
Iqbal, M., Chang, M. A., \& Iqbal, M. Z. (2003). Breeding behavior effects for yield, its components and fibre quality in Intraspecific crosses of cotton (Gossypium hirsutum L.). The Journal of Biological Sciences, 4, 451-459.

Mohammadi, S. A., \& Prasanna, B. M. (2003). Analysis of genetic diversity in crop plants - salient statistical tools and considerations. Crop Science, 43, 1235-1248. http://dx.doi.org/10.2135/cropsci2003.1235.

Moro, J. R., Silveira, F. T., \& Cargnelutti, A., Fo. (2007). Dissimilaridade genética em sessenta e quatro linhagens de milho avaliadas para resistência ao complexo enfezamento. Revista Biologia e Ciências da Terra, 7, 153-160.

Osorno, J. M., \& Carena, M. J. (2008). Creating groups of maize genetic diversity for grain quality: implications for breeding. Maydica, 53, 131-141. Retrieved from http://www.maydica.org/articles/53_131.pdf

Paixão, S. L., Cavalcante, M., Ferreira, P. V., Madalena, J. A. S., \& Pereira, R. G. P. (2008). Divergência genética e avaliação de populações de milho em diferentes ambientes no estado de Alagoas. Caatinga, 21, 191-195.

Rigon, J. P. G., Capuani, S., Cherubin, M. R., Rosa, G. M., \& Wastowski, A. D. (2012). Dissimilaridade genética de girassol por meio de caracteres quantitativos. Ciência Rural, 42, 1954-1959. http://dx.doi.org/10.1590/S0103-84782012001100008.

Rigon, J. P. G., Rigon, C. A. G., \& Capuani, S. (2014). Quantitative descriptors and their direct and indirect effects on corn yield. Bioscience Journal, 30, 356-362.

Rotili, E. A., Cancellier, L. L., Dotto, M. A., Peluzio, J. M., \& Carvalho, E. V. (2012). Divergência genética em genótipos de milho, no estado do Tocantins. Revista Ciência Agronômica, 43, 516-521. http://dx.doi.org/10.1590/S1806-66902012000300014.

Singh, D. (1981). The relative importance of characters affecting genetic divergence. Indian Journal of Genetics and Plant Breeding, 41, 237-245.

Tenaillon, M. I., U'Ren, J., Tenaillon, O., \& Gaut, B. S. (2004). Selection versus demography: a multilocus investigation of the domestication process in maize. Molecular Biology and Evolution, 21, 1214-1225. http://dx.doi.org/10.1093/molbev/msh102.

Troyer, F. A. (2006). Adaptedness and heterosis in corn and mule hybrids. Crop Science, 46, 528-544. http://dx.doi.org/10.2135/ cropsci2005.0065. 